It is devoid of all danger. The hæmorrhage is arrested the moment the wires (or wire) are raised to the necessary heat, and the patient suffers little or no inconvenience the moment the wires are withdrawn. I have used it with most satisfactory result, and I have before me a letter from Dr. P. C. Smyly, of Dublin, to a friend of his here, in which he states that he is much satisfied with its use. He says, the great thing is to injure the skin as little as possible, and to work with the point of the needle well under it. I must confess that I passed the wires through the skin and found no bad result from so doing, although I can well imagine by giving more time to the operation, and doing as be suggests, less deformity would be likely to arise-a consideration of much importance should the tumour be situated in a very conspicuous part of a female, or even on the face of a male.

Belle Vue, Clifton.

\section{THE WATER-SUPPLY OF MILITARY CANTONMENTS IN INDIA.}

\section{Br EDWARD NICHOLSON, F.C.S., ASSISTANT-SURGEON R.A.}

I HAVE just received the Army Medical Department Bluebook, containing the sanitary report by Dr. Muir, which has incurred the reprobatory remarks made by Surgeon-Major De Renzy in The Lancet of Sept. 7th. Dr. Muir's otservations are to the effect that, whilst much requires to be done in remedying possible defects in the details of waterconservancy, yet, on the whole, the European troops in India are provided with water adequate in quantity and wholesome in quality, and that the amount of disease traceable to defects in water-supply has been exaggerated. $\mathrm{Mr}$. De Renzy, on the other hand, is of opinion that " the supply is, with very few exceptions, so obviously exposed to contamination, that its use is attended with the gravest dangers to health." As, after eight years' regimental experience in India, I resumed my original chemical pursuits, and have been, for the last two years, charged with the duty of examining the water-supply of a large portion of the Madras Presidency, I may be permitted to give my testimony on the point.

It must first be remarked that Mr. De Renzy does not deny the statement made by Dr. Muir; his argument is that the water is exposed to possible contamination, and that, certain diseases of ill-ascertained origin being prevalent, they may be reasonably attributed to pollution of the water-supply. Having determined that the enteric fever of India is caused by excrement-tainted water, he proceeds to lay down that three-fourths of all deaths from fevers, and all the deaths from dysentery and diarrhœa, are caused by impure water; also that " the enormous quantity of impure water that men drink in the hot weather sufficiently explains the special prevalence of typhoid as well as of dysentery and diarrhcea at that season." It is hardly worth while refuting with argument conclusions which are simply jumped at; suffice it to say, that it is in no way proved that the drinking. water of soldiers contains impurity likely to cause either of the above diseases. It is taken for granted, because water is drawn by means of a leather bucket and conveyed in leather bags, that it is necessarily polluted-an assumption which I cannot grant; also that the wells are constantly exposed to pollution, and contain large deposits of filth-an assertion which is in no way confirmed by my special investigations on the subject. I admit that for various reasons it would be advantageous to raise water by machinery and distribute it by pipes, were there the slightest prospect of this system being cheaply and efficiently maintained, but I have very strong doubts if this measure would produce any improvement in health commensurate with the heavy out. lay. The system of water-carrying used in cantonments is that which is best adapted for use during the movements of troops, whether in the course of relief or on actual service, and as the establishment of water-carriers must be kept up, there is great economy effected by utilising them in cantonment. There is not the slightest evidence that carriage in skins has any bad effect on water, whilst, on the other hand, it is the custom amongst officers to keep their drinkingwater preferably in a leathern bottle, or chagul, from the pleasant coolness imparted by the porous leather. I consider that everything in reason has been done for the water-supply, if it is drawn and conveyed in the following manner:-

1. Water to be drawn from the well by the indigenous mechanical means of the Persian wheel, or the large leathern bucket, in either case worked by bullock-power.

2. To be.conveyed to barracks as at present, either by puckally bullocks (a bullock carries a pair of leathern bags or pukbals, each holding about twenty gallons), or in water-carts.

3. The water to be stored in porous pots (chatties) with covers.

4. Filtration, when necessary, to be effected by means of one large sand filter for the whole corps. Filtration through a foot or two of clean sand is sufficient for all practical purposes. The barrack-room water-pots would be filled from this filter.

I have not found that there is any practical inconvenience in the wells being open. I have never seen refuse or garbage in wells actually used, and the only case in which I can imagine the possibility of a dead dog being found in a well is in that of a water-hole, which only becomes a well in the rainy season, and at other times is used as a refuse depôt. Such a case could not occur unless the medical officer or the quartermaster grossly neglected his duty. I have always found the wells used for British troops to be fairly conserved, and without any certain signs of pollution in the water. Practically the only pollution to which a well is subjected is that of drippings from the puckally's feet when the well is so badly constructed that he is obliged to stand within the parapet, or that of bones or dung dropped by crows or other birds. The pollution thus caused, when distributed over the thousands of gallons of ten taken daily from it, must be, and practically is, infinitesimal. With acts of mischief I cannot deal; they are matters of police, and practically are most rare. In order to avoid all these sources of possible pollution (though evidence is wanting that any of them would produce disease) nothing is required but the ordinary exercise of the medical officer's authority. In nearly every station where the consumption of water is sufficiently large to justify the expense, indigenous mechanical appliances for raising water are in use, and a very slight increase of the quartermaster's subordinate establishment would suffice to guard the principal wells, and exercise the necessary supervision over the conveyance and storage of water. Some galvanised iron network would prevent birds from entering the well, or crows from dropping bones in to it.

I would most strongly deprecate the establishment of pumps and waterworks for cantonments in India, except under peculiar circumstances. The experiments that have been made in this line of sanitary engineering have been of the most discouraging character; I may even say that they form a notable feature in the great waste of public money made under the auspices of sanitation. We have a knack of always missing the happy mean in our military arrangements; we either stifle men in dens or else house them in palaces as uncomfortable as they are costly; we either take no care about their water-supply or we squander lacs of rupees on abortive waterworks. There is no doubt, however, that very fair progress was being made before the rise of what I may term the sanitary mania, and we had arrived at a very satisfactory general condition of health by 1860 . Since then we have done little else but waste money on extravagant schemes which have been entirely without practical advantages, and we have added what I may term the sanitary exploitation of India to the military and commercial exploitations which have already pauperised the country in the name of civilisation. The concluding paragraph of Mr. De Renzy's letter points to the infliction of "pumps and filters and condensers" on the native population of a cantonment as well as their establishment in barracks; that is to say, on the chance of saving one British soldier from the risk of enteric fever, thousands of his already heavily-taxed fellow-subjects are to be again heavily taxed under municipal regulations in order that in his rambles he may always come a ross drinking-water of guaranteed purity. 
I have found that throughout the stations of two-thirds of the British troops in this presidency, visited by me during the course of my Indian service, the water-supply has been generally quite as good as it is possible to obtain without an outlay incommensurate with the very problematical advantages expected. It may be said, however, that my experience, being confined to Madras, cannot be taken as evidence on the water-supply of Bengal. But I have had the opportunity of studying the reports on the four years of water-analysis in Bengal, and the advantage of visiting a Bengal station very much written about by the Indian sanitary authorities of that province. The former has enabled me to confirm fully Dr. Mouat's opinion that, "with few exceptions, the supply is adequate and wholesome"; and the latter to go even further than him in deprecating the exaggerated ideas current on the state of Indian watersupply generally.

The reports on the waters of Bengal cantonments are, unfortunately, of the most unsatisfactory description, as neither the superintendent of the analyses nor the analysts themselves appear to have had any chemical education beyond that obligatory on every medical officer. As far as I am able to sift the real facts out of the figures and remarks given, the water-supply is of good quality except in those stations where a naturally saline subsoil has imparted brackishness to the water.

My personal experience of Bengal is confined to a town which I visited expressly to examine a water-supply stated to be entirely polluted, not only by freal, but also by choleraic, matter. The following are a few of the remarks made by sanitary authorities on Pooree:-

"The water-supply of that town is polluted to the last degree by choleraic matter...... The water in the tanks and wells of Pooree is loaded with choleraic matter in the greatest degree." (Circular by F. J. Mouat, M.D., InspectorGeneral of Gaols, March 4th, 1868.)

"The sources of water-supply have been polluted from time immemorial. ...... I believe most of the tanks to be in the same condition as that now indicated [i.e., evolving noxious gases]; and I have no doukt that by percolation the water of almost all the wells in the city is very seriously contaminated." (Report on Pilgrimage to Juggernauth in 1868, by David B. Sneith, M.D., Sanitary Commissioner for Bengal.)

I had my suspicions that these descriptions were highly coloured, as the language of Indian sanitary science is notoriously hyperbolical. Thus Dr. David B. Smith, wishing to express the fact that the streets of Pooree were illsmelling, uses the following terms: "There is a universal dearth of oxygen; carbonic acid, ammonia, carburetted and sulphuretted hydrogen abound to a poisonous degree. Words fail me as I endeavour to depict the whole truth." I need hardly remark that thore is not the slightest evidence of Dr. David B Smith's having ascertained even the presence, much more the quantity, of the above gases in the atmosphere. And considering that Pooree is on the seashore, swept by a constant sea breeze, I have my doubts as to whether analysis would detect any notable deficiency of oxygen. The town is not dirtier than the average of purely Indian towns.

But returning from the quality of the air to that of the water, I found, on analysis of typical tank- and well-waters, that there was no evidence whatever of sewage pollution, and that the natural water-supply, though generally brackish, was as good as that in any town on the Eastern coast from Madras to Calcutta, both included. I have a strong impression that the only foundation for the assertion that the waters are "loaded with choleraic matters" is that the more brackish waters contain much chlorides: cholerastools contain chlorides, the Pooree waters contain much chlorides; the inference is obvious. Such reasoning, however absurd, is quite on a par with the assertion that there is a universal dearth of oxygen in the air of the town.

It will be seen that my personal experience of Bengal corroborates Dr. Muir's statement that the condition of the water-supply has been exaggerated, in a great measure owing " to the water question being mixed up with theories of cholera and other epidemic diseases." I will go so far as to say that, in my experience, it is exaggerated in order to make it fit in with theories of cholera and other epidemic diseases.

Bangalore.

\section{a cattiturot}

\section{HOSPITAL PRACTICE, BRITISH AND FOREIGN.}

Nulla autem est alia pro certo noscendi via, nisi quamplurimas et morborum et dissectionum historias, tum aliorum, tum proprias collectas habere, et inter se comparare.-MorgagN I De Sed. et Caus. MLorb., lib.iv. Proœmium.

\section{CHARING-CROSS HOSPITAL.}

CASE OF PRIAPISM LASTING SIX WEEKS; RECOVERY. (Under the care of Mr. Hird.)

Persisrenct priapism is sometimes met with in cases of disease or injury of the spinal cord or cerebellum, but apart from morbid conditions of these organs it is exceedingly rare. Many works devoted specially to diseases of the male genital organs do not even allude to this condition, and in no work on surgery is any but a very brief mention made of it. In The Lancer, vol. i. 1867, p. 207, a case is reported which was under the care of Mr. Birkett in Guy's Hospital; and at the same place three other cases are referred to, the first of which occurred in 1824 in the practice of $\mathrm{M}$ r. Callaway, and which lasted for nearly three weeks; $;$ the second was for four days under the treatment of Mr. John W. Tripe of Hackney, and subsequently for four months under the care of Mr. Luke in the London Hospital ; $\uparrow$ and the third, which lasted over a month, was a patient under Dr. Handfield Jones at St. Mary's Hospital in the early part of the year 1867. Since then two other cases have been recorded in the Nev Orleans Journal of Medicine: the first in January, 1869, by Dr.J.R. Smith; the second in the July number of the same year, by Dr. Hargis. Dr. Gross refers in his work "On Surgery" to a case of this kind which he saw many years ago. In the majority of the cases the priapism seems to have been due to excessive coitus; but in the subjoined case no such exciting cause was present. In some, moreover, there was increased sexual desire for some time after the onset of the disease; but in most of the cases this did not exist. The pathology of this condition is very obscure. By some it is considered to be the result of extravasation of blood; by others to be due to nervous refiex irritation. The effect of treatment seems to indicate the latter as being the more correct; for incisions into the penis, to let out the extravasated blood, have not been productive of any good result, whereas the administration of bromide of potassium has, in several instances, been followed by relief and gradual subsidence of the symptoms.

For the notes of the following case we are indebted to Dr. Mitchell Bruce.

C. C- aged fifty-five, an Irishman, and a porter at Covent-garden, was admitted into hospital on Sept. 28 th, 1872. The patient, according to his own account, had been a healthy man, with the single exception that three years ago he suffered from priapism for three or four days, the affection coming on suddenly in the day time, and gradually passing off. The priapism was accompanied by severe pain in the penis, but by no symptom in the back, legs, bladder, or bowels. Since the time indicated the patient had not suffered from any such disease in any degree until the present. The patient was confessedly a drunkard; every day, or every second day, he was drunk upon rum; he never had less than four quarterns a day. He also stated that he had neither lately nor at any time been given to sexual excess. On Sept. 23rd, about 4 A M., the patient awoke to find his penis erect and painful, after no provocation whatever; and this condition continued up to his admission.

On being admitted, the patient was found to be suffering from well-marked priapism, with constant pain in the penis. The organ was very tender, but there was no redness at any spot on it, or in the neighbourhood, nor was there any distortion or want of uniformity in the considerable and general unnatural enlargement. The patient lay on his back, with his knees drawn up, to prevent the contact of the bedclothes. The pain in the penis prevented sleep. There was no pain in the back, no pain or other abnormal * London Medical Repository, 1824, p. 286.
+ THE LANCET, July, 1845. 